Antibacterial activity of Canavalia ensiformis L.DC seeds due to solvent extract and fraction method

\author{
M. Pugalenthi, A. Doss, D. Rajendrakumaran and V. Vadivel ${ }^{1}$ \\ Department of Botany, Government Arts College, 'Department of Biotechnology, Karpagam Univ., Coimbatore, India \\ pugalmuthiah@rediffmail.com
}

\begin{abstract}
The study was performed to evaluate the antibacterial activity of Canavalia ensiformis L.DC. seeds, against clinically important pathogenic bacteria: S. aureus, B. subtilis, S. pyrogens, E. coli, S. typhi, P. vulgaris, P. aeruginosa and $K$. pneumonia using methanol extract and its fractions in water: chloroform. The methanol extract exhibited better inhibitory activity (MIC < or $=0.125$ to $4.0 \mathrm{mg} / \mathrm{L}$ ) against many test bacteria compared to the extract fractions.
\end{abstract}

Keywords. Canavalia ensiformis, methanol extract, antimicrobial activity, MIC.

Introduction

A large number of pharmacological investigations have been directed towards the plant kingdom as a source of therapeutic agents. They are effective in the treatment of infectious diseases while simultaneously mitigating many of the side effects that are often associated with synthetic antimicrobials (Yerra rajeshwar et al., 2005). Plant based antimicrobials represent a vast untapped source for medicines and further exploration needs to occur. Seeds use strategies to germinate and survive in soils that are densely inhabited by a wide range of microfauna and microflora. Various antimicrobial proteins such as chitinases, $\beta$-glucanases, thionins, ribosome-inactivating proteins and permatins have been detected in seeds. These are believed to play a role in plant defense because of their strong antimicrobial activity.

The Canavalia ensiformis is an annual plant, shrub, erect or climbing, 1 to 2 meters height and its leaves have a length of 6 to $12 \mathrm{~cm}$, oval - elliptical, white hair with regular density. The plant produces an average of 7 pods linear, slightly curved, 25 to $30 \mathrm{~cm}$ long by 3.5 wide capsules. Its seed weight is about 1.5 grams which are white and shiny, and measures about 21-22 x 14-15 x 8$10 \mathrm{~mm}$ (Sauer, 1964). Canavalia seed is considered a non-conventional source of high protein content; however it has not yet been released for human use because of the toxic compounds that show, such as hemagglutinin, trypsin inhibitors, analogues of amino acids, among others. Studies have been suggested to reduce the level of toxicity with these protein bodies including the heating, fermentation and extrusion without obtaining favorable results (Cira-Chavez et al., 2009). This is the first paper describing the antimicrobial activity of the seed extracts of C. ensiformis L.DC.

Materials and methods

Plant material

The seeds of Canavalia ensiformis were collected in May, 2009 at Erode Dt., Tamilnadu, India. The seeds were identified in Botanical Survey of India (Southern Circle), Coimbatore. A voucher specimen of the plant has been deposited at the Department herbarium. The seeds were cut into bits and dried in the open for 5 days. The dried seeds were then powdered using an electric mill.

Preparation of the total extract

$250 \mathrm{~g}$ of C.ensiformis seed powder was extracted with $1.5 \mathrm{~L}$ of methanol over $48 \mathrm{~h}$. The extract was reduced to dryness in a rotary evaporator to yield $32.18 \mathrm{~g}$ $(12.48 \%, w / w)$ of the crude methanol extract.

Fractionation of the total extract

$32.18 \mathrm{~g}$ of the crude methanol extract was partitioned into chloroform and water (1:1) using a separating funnel. The separated fractions were concentrated to dryness using a rotary vapour. The yield of the chloroform fraction was $2.18 \mathrm{~g}(6.4 \% \mathrm{w} / \mathrm{w})$ and that of the aqueous fraction was $3.02 \mathrm{~g}(8.9 \% \mathrm{w} / \mathrm{w})$. The crude ethanol extract and the separated fractions were used for the antimicrobial studies.

\section{Test organisms}

The organisms used in this study were clinical isolates of $S$. aureus, B. subtilis, S. pyrogens, E. coli, S.typhi, P.vulgaris, $P$. aeruginosa and K. pneumonia. These were all supplied by the Dept. of Microbiology, RVS College of Arts and Science, Sulur, Coimbatore, Tamilnadu.

\section{Antimicrobial activity}

The antimicrobial test was performed by following agar disc diffusion method (Perez et al., 1990; Bauer \& Kirby, 1996; Salie et al., 1996; Nair \& Chanda, 2005) using Mueller Hinton Agar No. 2 medium. Microbial growth was determined by measuring the diameter of the inhibition zone (SD \pm Mean).

\section{Determination of minimum inhibitory concentration}

Various concentrations of the seeds of C.ensiformis, ranging from $8.0-62.5 \mathrm{mg} / \mathrm{ml}$ were introduced into different test tubes; each tube was inoculated with an overnight culture of Staphylococcus aureus, Proteus vulgaris, Streptococcus pyrogens, Escherichia coli, Salmonella typhi, Proteus vulgaris , Klebsilla pneumoniae, and Pseudomonas aeruginosa, diluted to give a final concentration of $10^{6}$ cells per $\mathrm{ml}$. The tubes were incubated at $37^{\circ} \mathrm{C}$ for $24 \mathrm{~h}$ (Collins et al., 1995).

Determination of minimum bactericidal concentration
Research article

CIndian Society for Education and Environment (iSee)
"Antimicrobial activity of Canavalia ensiformis " http://www.indjst.org
Pugalenthi et al. Indian J.Sci.Technol. 
After culturing the test organisms separately in nutrient broth containing various concentrations of the active ingredients, the broth was inoculated onto freshly prepared agar plates to assay for the bactericidal effect. The culture was incubated at $37^{\circ} \mathrm{C}$ for $24 \mathrm{~h}$. The lowest concentration of alkaloid that does not yield any colony growth on the solid medium after the incubation period was regarded as minimum bactericidal concentration (MBC) (Alade \& Irobi, 1995).

Table 1. Antibacterial activity of Canavalia ensiformis L.DC

\begin{tabular}{|l|c|c|c|c|}
\hline \multirow{2}{*}{ Microorganisms } & \multicolumn{2}{|c|}{ Zone of Inhibition (mean \pm SD) } & Ciproflo- \\
\cline { 2 - 4 } & Methanol & Aqueous & Chloroform & xacin $25 \mu \mathrm{g}$ \\
\hline Staphylococcus aureus & $23 \pm 1.0$ & $15 \pm 1.0$ & $11 \pm 0.577$ & 29 \\
\hline Streptococcus pyrogens & $20 \pm 1.0$ & $15 \pm 0.57$ & $10 \pm 0.577$ & 24 \\
\hline Bacillus subtilis & $18 \pm 0.57$ & $14 \pm 1.154$ & $12 \pm 1.0$ & 28 \\
\hline Escherichia coli & $18 \pm 0.57$ & $12 \pm 1.154$ & $9 \pm 0.577$ & 30 \\
\hline Pseudomonas aeruginosa & $16 \pm 0.57$ & $9 \pm 0.577$ & $9 \pm 0.577$ & 27 \\
\hline Klebsilla pneumonia & $15 \pm 1.0$ & $11 \pm 0.577$ & $11 \pm 0.577$ & 20 \\
\hline Proteus vulgaris & $13 \pm 1.0$ & $10 \pm 0.577$ & $11 \pm 0.577$ & 22 \\
\hline Salmonella typhi & $16 \pm 1.0$ & $10 \pm 1.154$ & $10 \pm 1.0$ & 21 \\
\hline
\end{tabular}

Results and discussion

ymers of several Gram-negative and Gram-positive microorganisms (Reda Helmy Sammour \& Abd-ElRaheem R. El-Shanshoury, 1992). Amongst the gram positive and gram negative negative bacteria, grampositive bacterial strains were more susceptible to the extracts when compared to gram negative bacteria. This may be attributed to the fact that these two groups differ in their structure of the cell wall components (Erasto et al., 2004). The results of the present study suggest that the tannins isolated from the seeds of $C$. ensiformis possess remarkable antibacterial activity against microbial pathogens.

\section{Acknowledgement}

Authors thank UGC for the financial support under Major Research Project (Sanction No. F. No. 35-37 / 2008 (SR) dt 19.03.2009), and Management \& Administrative authorities of Karpagam Educational Institutions for their encouragement \& support.
The results for the antimicrobial sensitivity tests (inhibition zone diameters $(\mathrm{mm})$ for the extracts (at 50 $\mathrm{mg}$ ), standard antibacterial doses, ciprofloxacin $25 \mu \mathrm{g}$ against the clinical pathogens are given in Table 1 . The crude methanol extract was the most active of the three extracts showing activity against all the isolates. The aqueous and chloroform fractions were very active against S.aureus, S.pyrogens, E. coli, $P$. aeruginosa and $K$. pneumoniae. The results further showed that the methanol extract exhibited almost similar activity (zone diameters) as amoxicillin against $S$. aureus, $B$. subtilis, $S$. pyrogens and E.coli. The activities of methanol extract, aqueous fraction and chloroform fraction against $S$. aureus were, in descending order viz; crude methanol extract $>$ aqueous fraction $>$ chloroform fraction. The activity of methanol extract against Gram-positive organisms was in descending order of $S$. aureus $>S$. pyrogens $>B$. subtilis. Also, the various extracts showed better activity against the Gram negative organisms, when compared with the standard ciprofloxacin, since the latter only showed activity against $E$. coli at the dose tested. The minimum inhibitory concentrations (MICs) of the extracts and fractions are shown in Table 2. This varied between $0.125-4.0$ $\mathrm{mg} / \mathrm{ml}$ against all the bacterial strains used in this study. The superior activity of methanol extract compared with aqueous and chloroform fractions were clearly demonstrated against the tested microorganisms.
Table 2. Minimum inhibitory concentrations and minimum bactericidal concentrations

\begin{tabular}{|l|c|c|}
\hline Microorganisms & $\begin{array}{c}\mathrm{MIC} \\
(\mathrm{mg} / \mathrm{ml})\end{array}$ & $\mathrm{MBC}$ \\
\hline S. aureus & 2.5 & + \\
\hline S. pyrogens & 0.5 & - \\
\hline B. subtilis & 1.0 & - \\
\hline E.coli & 4.0 & + \\
\hline P. aeruginosa & 2.0 & + \\
\hline K. pneumonia & 1.0 & + \\
\hline P. vulgaris & 2.0 & - \\
\hline S. typhi & 2.0 & + \\
\hline
\end{tabular}

\section{References}

1. Alade, PI and Irobi ON (1995) Antifungal activities of crude leaf extract of Acalypha wilesiana. J. Ethnopharmacol. 39, 171-174.

2. Bauer AW and Kirby WMM (1966) Antibiotic susceptibility testing by a standardized single disk method. $A m \mathrm{~J}$ Clin. Pathol. 45, 493-496.

3. Cira-Chavez LAA, Minor-Perez HB, Dublan-Garcia OC and Garcia-Barrientos RD (2009) Effect of germination on the physicochemical properties of Canavalia (Canavalia ensiformis). World Acad. Sci., Engg. Technol. 54, 673-675.

4. Collins GH, Lynes PM and Grange JM (1995) Microbiological methods. 7th edn., Butterwort - Heinemann Ltd., Britain. pp: 175-190.

5. Erasto P, Bojase-Moleta G and Majinda RRT (2004) Antimicrobial and antioxidant flavonoids from the roots wood of Bolusathus spesiosus. Phytochem. 65, 875-880.

6. Nair R and Chanda S (2005) Anticandidal activity of Punica granatum exhibited in different solvents. Pharm. Biol. 43, 21 25.

7. Perez C, Paul M and Bazerque P (1990) An antibiotic assay by the agar-well diffusion method. Acta Biol. Med. Exp.15, 113-115.

8. Reda Helmy Sammour and Abd-ElRaheem R. El-Shanshoury (1992) Antimicrobial activity of legume seed protein. Bot. Bull. Academia Sinica. 33, 185-190.

9. Salie F, Eagles PFK and Leng HMJ (1996) Preliminary antimicrobial screening of four South African Asteraceae species. J. Ethonopharmacol. 52, 27-33.

10. Sauer J (1964) Revision of Canavalia. Brettonia.16, 106-181.

The legume seeds contain lectins and protease inhibitors that are reported to have antimicrobial activity. Interactions with seed lectins have been used to obtain structural information about the Cell envelop and cell wall
11. Yerra Rajeshwar, Malaya Gupta and Upal Kanti Mazumder (2005) In Vitro lipid peroxidation and antimicrobial activity of Mucuna pruriens seeds. Iran. J. Pharmacol. \& Therapeutics. 4, 32-35.
Research article

CIndian Society for Education and Environment (iSee)
"Antimicrobial activity of Canavalia ensiformis " http://www.indjst.org
Pugalenthi et al. Indian J.Sci.Technol. 